\title{
Breast Cancer pT1c TNM Finding v8
}

National Cancer Institute

\section{Source}

National Cancer Institute. Breast Cancer PT1C TNM Finding v8. NCI Thesaurus. Code C139420.

Breast cancer with tumor size more than $10 \mathrm{~mm}$, but not more than $20 \mathrm{~mm}$ in greatest dimension. (from AJCC 8th Ed.) 